\title{
An Investigation of Litigation Process in Construction Industry in Turkey
}

\author{
Murat ÇEVÍKBAŞ ${ }^{1}$ \\ Almula KÖKSAL ${ }^{2}$
}

\begin{abstract}
Projects are laden with variety of uncertainties depending on their respective characteristics. Construction projects also have their own distinctive characteristics, such as technologies applied and numerous uncertainties. Thereby, it is highly probable that disputes could be encountered between concerned parties. While resolving these disputes, unspecialized legal professionals conducting construction related cases would increase the number of unsatisfactory judicial results. In this study, it is aimed to classify the most frequent dispute sources concerning the construction sector and to identify the qualifications and competency levels of concerned judicial actors. Correspondingly, 282 cases between 2007 and 2017 in Turkey are classified regarding relevant contents and analyzed. These cases are extracted from legal websites. While elaborating the cases, content analysis is performed in order to categorize the sources of disputes. Moreover, by inspecting the judgments of Court of Cassation for each case, qualifications and competency levels of judicial actors are questioned. In conclusion, the main dispute sources are classified under 5 headings along with some associated subheadings. Among the subheadings, construction works, construction contracts, debits and credits are detected as the most frequent dispute sources. Secondly, in majority of the cases, reassessment decisions were given by Court of Cassation due to inadequate competency levels of Court of First Instance and expert reports.
\end{abstract}

Keywords: Disputes in construction, competency levels of legal actors, legal process in construction, content analysis.

\section{INTRODUCTION}

A project is a systematic process requiring finite resources to achieve stakeholders' objectives which are defined in a contract. A stakeholder can be a person or an organization affected by the project outcomes positively or negatively [1], [2]. Level of responsibility, power and expectation of stakeholders may vary from project to project [2]. Tendency to maximize the

Note:

- This paper has been received on February 03, 2018 and accepted for publication by the Editorial Board on July $04,2018$.

- Discussions on this paper will be accepted by January 31, 2019.

- DOI: $10.18400 /$ tekderg.389757

1 Yildiz Technical University, Department of Architecture, İstanbul, Turkey - muratcevikbas@sdu.edu.tr

2 Yildiz Technical University, Department of Architecture, İstanbul, Turkey - almulakoksal@yahoo.com 
benefit of each stakeholder may cause conflicts of interest and may result in disputes. Therefore, the construction sector is also identified as a dispute ridden industry as well. Litigation is the most formal way and the final destination in terms of settling disputes in Turkey, and it is time and cost consuming in addition to several other disadvantages [3]. According to Oxford Business Group [4], economy of Turkey is driven by the construction sector. Although there is widespread dissatisfaction among parties leading to the litigation process [5] along with its concomitant cost and time overrun and adversarial relationships [6], [7], unfortunately, Turkish construction industry mostly applies to litigation before trying other dispute resolution methods.

Understanding the factors influencing the occurrence of disputes determines the performance of a construction project [8], [9]. Although the subject of dispute resolution is widely discussed in literature, there are limited studies related to inspecting the efficiency of the litigation process in construction industry. Apanoğlu [10] initiated a study to determinine the frequency of dispute types according to only Contract of Work in "Turkish Code of Obligations". He investigated the cases until 2007. However, in addition to Contract of Work, other significant classifications and their cross-tabulations are needed in order to provide an in-depth analysis. Additionally, while these cases conducted by Court of Cassation are overviewed, judgments of Court of Cassation are to be analysed in order to determine the weaknesses of the concerned actors. To do this, extensive literature review is conducted, and construction related lawsuits from 2007 to 2017 are reviewed and analyzed as a quantitative method through SPSS in this research. To analyse the data, content analysis is used. The main purpose of content analysis is to transform the qualitative data to quantitative data through classification. Thus, dispute categories including the main dispute reasons are generated and competency levels of judicial actors are questioned. Content analysis is generally utilized in social science aiming to systematically examine the data obtained from different sources such as documents, archives, newspapers, television series, cinemas, etc. [11]. According to Yıldırım A. and Şimşek H. [12], content analysis allows the researcher to investigate the summarised and interpreted data through an in-depth descriptive approach in order to figure out the hidden themes. Additionally, Yıldırım and Şimşek [12] underline the importance of content analysis as gathering similar data as per defined themes through an inductive approach. In this study, contents of the cases are classified according to following categories; articles in Contract of Work in Code of Obligations, dispute types, project types, scope of construction project contract, and decisions by Court of Cassation. After the cases are grouped as per type of the disputes, frequency analysis is made in order to figure out the occurrence rates of the categories statistically. Hence, contract related cases conducted by Court of Cassation between 2007 and 2017 are categorized to determine the sources of the disputes and bottlenecks of the participating actors in order to be able to take crucial precautions concerning construction projects in advance. The reasons behind limiting the cases with only the ones having construction project contracts and judged by Court of Cassation are given below;

- Construction project contract is one of the most vital tools hindering disputes,

- Decisions of Court of Cassation set a precedent for future cases,

- Decisions of Court of Cassation are disclosed for public use through legal websites, 
As in industries related to Medicine and Information Technology (IT), construction industry has its own characteristic elements and requires specific knowledge to resolve the disputes between the parties; still, in current judicial process in Turkey, judicial actors mostly have bachelor's degree without specializing in a specific subject. Thus, projects' parties in the construction sector encounter numerous problems during the resolution of disputes through litigation. In order to settle these problems, this study intends to achieve the following goals;

1. To detect the problem areas in the content of the cases concerning construction industry along with their occurrence rates through classifications of disputes.

2. To identify the competency levels and qualifications of judicial actors who participated in construction related disputes in Turkey.

\section{THE LITIGATION PROCESS}

Litigation is one of the most effective and common methods used to resolve a dispute. Ilter [13, p. 589] expresses in her study that "In most disputes, parties try negotiation and if this is not successful, dispute is taken to arbitration or litigation right away." This process is managed by a judge in order to release a binding decision. However, there are some disadvantages such as the case being relatively slow and being an expensive process along with the potential of damaging the business relationship.

Court of First Instance (Trial Court) is the first level of courts handling any type of disputes. It contains two main organizations namely, civil and criminal divisions in order to conduct civil and criminal issues respectively. Civil Courts consist of Civil Courts of Peace, Civil Courts of General Jurisdiction and Specialized Courts. Criminal Courts contain divisions as General Criminal Courts and Specialized Criminal Courts. If a Specialized Court doesn't exist in a district, concerned Civil Courts or General Criminal Courts have the authority to judge on behalf of Specialized Courts. Generally, construction cases are conducted by Civil Courts of General Jurisdiction.

Following the verdict for the case by the Court of First Instance, should one of the parties is not satisfied, the parties of the dispute have the right to apply to the Regional Courts of Justice. Then, the process extends again. With respect to application to Regional Courts of Justice for appeal, the deposited amount for the lawsuit shall be higher than $3.110 \mathrm{TL}$ as of January 01, 2017 excluding libel suits which don't require a limit according to Article 341/2 in the Law of Civil Procedure [14]. If the claimant or defendant is not satisfied with the decision of the Regional Court of Justice than the amount for the lawsuit would be higher than $41.530 \mathrm{TL}$ as of January 01, 2017, claimer can thus apply to the Court of Cassation.

Before the establishment of Regional Courts of Justice, Court of Cassation was responsible for appeal. Regional Court of Justice was established on September 26, 2004 with the law number 5235 and came into force in July 2016. Above the Regional Courts of Justice, Judicial Justice is conducted by Court of Cassation in Turkey. This organization constitutes 23 Civil Chambers and 20 Criminal Chambers which have their own individual roles. Civil Chambers in the Court of Cassation are charged to deal one of the following decisions [14];

- If a Civil Chamber in the Court of Cassation agrees with the award dealt by the Courts of First Instance, the award is accepted. 
- If the Civil Chamber disagrees with the award dealt by the Courts of First Instance and asks reassessment, the Court of First Instance either accepts the reassessment or rejects the decision of reassessment. If the Court of First Instance agrees with the award of the Civil Chamber, the case is opened again and the decision is changed as per law. If the decision of reassessment is rejected by the Court of First Instance, the case is reviewed by the General Assembly of Civil Chamber in the Court of Cassation instead of the Civil Chamber.

Structure of Judicial Justice is illustrated in Organizational Figure 1 below.

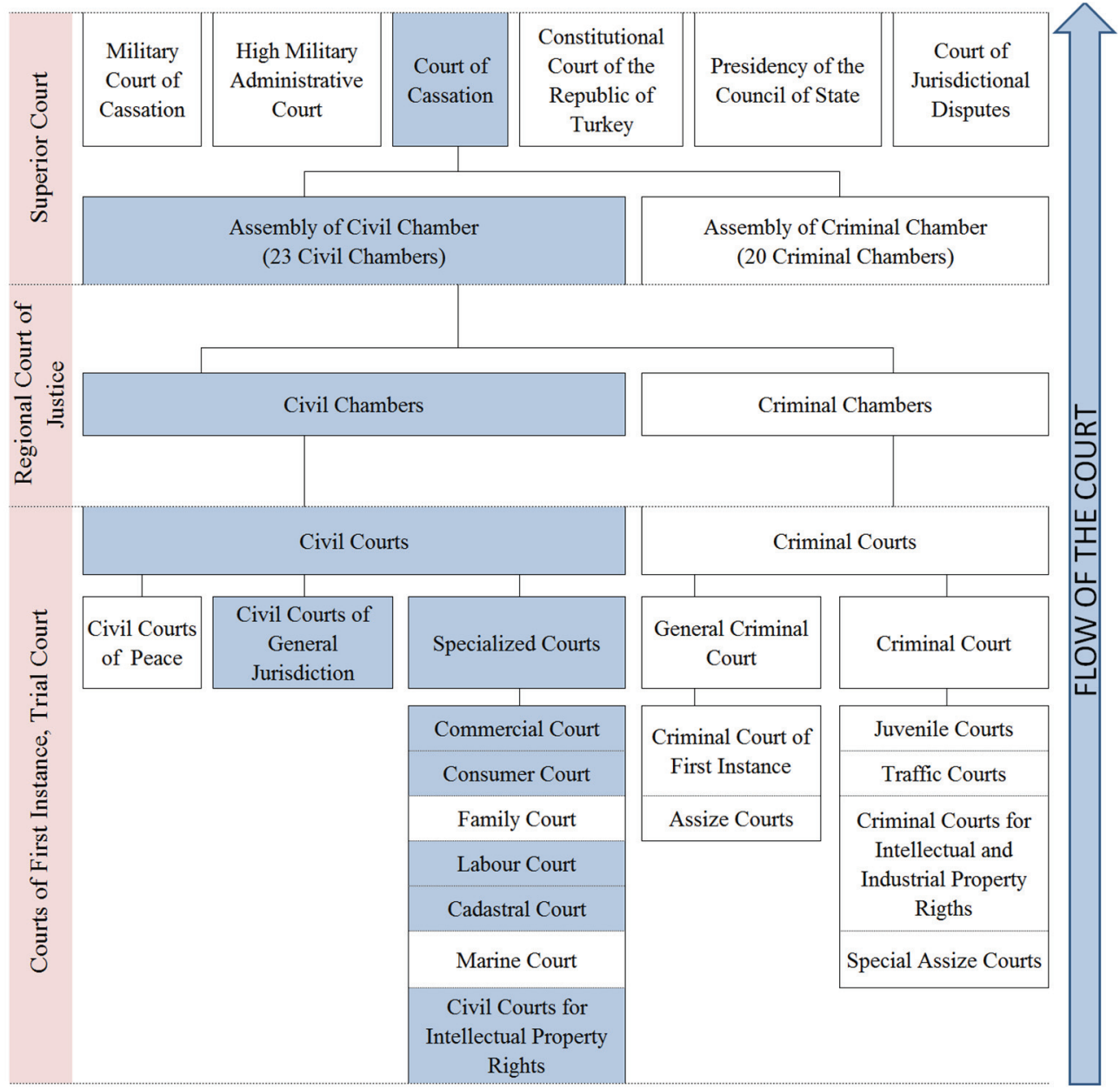

Figure 1. Organization of judicial justice in Turkey [15], [16]

In Figure 1, cases related to construction industry are mostly conducted by the courts shaded in blue above. 
General Law consists of Public and Private Law. Disputes in Turkish private construction industry are ruled by Private Law. In this study, cases resulting from private projects with contracts are focused. Contract related cases are conducted as per Contract of Work which is part of Code of Obligations. Code of Obligations was transferred from Swiss Code of Civil Law and was established on April 22, 1926 with a law number 818. Then, the final update entered into force on January 01, 2011 with the law number 6098 and started to be used on July 1, 2012 [15]. Code of Obligations \# 6098 contains 18 parts and mainly defines the relationship between debtor and creditor through related articles from 1 to 649 . Part 7 in the Code of Obligations allocates Contract of Work which defines statements in a contract in terms of scope, liabilities, payment and termination [17]. Contract of Work covers the articles from 470 to 486, which correspond to the articles from 355 to 371 in the Code of Obligations \# 818. In this study, article numbers in both Code of Obligations 818 and 6098 are utilized during the reviewing phase of the cases as the study covers the cases from 2007 to 2017 .

\section{METHODOLOGY AND RESULTS}

In order to achieve the objectives of the study, 420 cases examined by the Court of Cassation between 2007 and 2017 are reviewed, and 282 cases are found to be related to the construction industry. The cases are elaborated and content analysis is applied in order to categorize the main dispute sources and define the qualifications and competency levels of judicial actors. By doing this, concerned cases are classified as per articles in Contract of Work, dispute types, project types, scope of construction project contract, and decisions made by Court of Cassation in order to define the most sensitive dispute areas and to define the qualifications and competency levels of judicial actors. After the cases are categorized as per concerned contents, frequency analysis is made in order to determine the occurrence rate of each dispute content.

To serve the goals mentioned above, a summary of the classifications of elements related to the content and their objectives are tabulated in Table 1 below.

Table 1. Summary of the classifications and their objectives

\begin{tabular}{|l|l|}
\hline CLASIFICATION & PURPOSE \\
\hline $\begin{array}{l}\text { Articles in Contract of } \\
\text { Work }\end{array}$ & $\begin{array}{l}\text { To reveal the crucial articles in Contract of Work in terms of } \\
\text { dispute }\end{array}$ \\
\hline Dispute Types & To identify the major sources of the disputes \\
\hline Project Types & $\begin{array}{l}\text { To determine the most frequent project types leading to } \\
\text { disputes }\end{array}$ \\
\hline $\begin{array}{l}\text { Scope of Construction } \\
\text { Project Contracts }\end{array}$ & $\begin{array}{l}\text { To determine the most frequent Articles of Construction } \\
\text { Project Contracts leading to disputes }\end{array}$ \\
\hline $\begin{array}{l}\text { Decisions made by the } \\
\text { Court of Cassation }\end{array}$ & $\begin{array}{l}\text { To define the qualifications and competency levels of judicial } \\
\text { actors }\end{array}$ \\
\hline
\end{tabular}


The obtained data is analysed through SPSS. According to the outcome of the analysis, tables from 2 to 7 are developed. To begin with, the frequency of article numbers is defined in Table 2 below.

Table 2. Frequency of Articles in Contract of Work

\begin{tabular}{|c|c|c|c|}
\hline $\begin{array}{c}\text { Articles } \\
\quad \#\end{array}$ & Description & $\begin{array}{c}\# \text { of } \\
\text { Cases }\end{array}$ & $\begin{array}{l}\text { Percent } \\
(\%)\end{array}$ \\
\hline $470 / 355$ & Contract & 197 & 69.9 \\
\hline $471 / 356$ & General responsibilities of contractor & 7 & 2.5 \\
\hline $472 / 357$ & Material & 6 & 2.1 \\
\hline $473 / 358$ & Commencement of work and defect in execution & 5 & 1.8 \\
\hline $474 / 359$ & $\begin{array}{l}\text { Indication of defect of work by Client after } \\
\text { handing over }\end{array}$ & 12 & 4.3 \\
\hline $475 / 360$ & Client rights resulted from defects of work & 10 & 3.5 \\
\hline $476 / 361$ & $\begin{array}{l}\text { Defects caused by client and warned by } \\
\text { contractor }\end{array}$ & 2 & 0.7 \\
\hline $477 / 362$ & Acceptance of work & 9 & 3.2 \\
\hline $478 / 363$ & $\begin{array}{l}\text { Time limit of opening a case due to defects of } \\
\text { work }\end{array}$ & 1 & 0.4 \\
\hline $479 / 364$ & Due date of payment & 2 & 0.7 \\
\hline $480 / 365$ & Lump sum price & 11 & 3.9 \\
\hline $481 / 366$ & $\begin{array}{l}\text { Price as per value (Unit measure and Cost plus } \\
\text { fee) }\end{array}$ & 17 & 6.0 \\
\hline $483 / 368$ & Destruction of work before completion & 1 & 0.4 \\
\hline $484 / 369$ & $\begin{array}{l}\text { Cancelling the contract through paying } \\
\text { completed work }\end{array}$ & 2 & 0.7 \\
\hline Total & & 282 & 100.0 \\
\hline
\end{tabular}

It should be noted that there are some changes in law and in codes of law during the period of 2007-2017. In year 2012, a new Code of Obligations was released, and article numbers for the law 818, which refers to the previous law, and law number 6098 , which refers to the final Code of Obligations, are introduced in Table 2 above in order to refrain from confusion. In the first column of Table 1, while the first number in each row refers to the final release of Code of Obligations \# 6098, the following number refers to the previous Code of Obligations \# 818.

Each article shown in Table 2 defines the frequency of dispute areas as per Contract of Work. Since each construction related dispute in this study pertains to a contract, the contract becomes the most sensitive issue. This also correlates with Bvumbwe C. and Thwala D. W. 
[18]'s study in which poor contracts are identified as one of the major causes of disputes in construction industry. Detailing each article concerning the parties' expectations and eliminating the ambiguities in construction project contracts are believed to prevent disputes in projects.

As depicted in Table 2, the main definition of Contact of Work namely, Article 470/355 (Contract) constitutes the biggest part of the examined cases by almost $70 \%$. The term of Contract as an article expresses all the general contract related disputes. In other words, it is a definition term of 'Contract of Work'. Therefore, categorising the cases as per only Contract of Work provides missing information. In order to deeply investigate the main dispute areas, dispute types are essential to be grouped and elaborated as per defined contents, namely 'Dispute Types', 'Project Types', 'Scope of Construction Project Contract', 'Decisions by Court of Cassation' and their relevant cross tabulation between each other in this study. Therefore, the next assessments shown in the following tables namely, Table 3, 4 and 5 intend to serve this purpose.

After all the cases are reviewed in terms of their subjects, firstly, dispute types are aggregated as 'Debit and Credit', 'Cancellation of Contract', 'Defective Products', 'Delay', 'Occupational Accident' and 'Registration and Nullification for Deed and Title'. Frequencies of concerned dispute types are tabulated in Table 3 below.

Table 3. Frequency of Dispute Types

\begin{tabular}{|l|l|l|}
\hline Dispute Type & \# of Cases & Percent (\%) \\
\hline Debit and Credit & 142 & 50.4 \\
\hline Defective Products & 63 & 22.3 \\
\hline Delay & 32 & 11.3 \\
\hline Termination of Contract & 22 & 7.8 \\
\hline Registration and Nullification for Deed and Title & 21 & 7.4 \\
\hline Occupational Accident & 2 & 0.7 \\
\hline Total & 282 & 100.0 \\
\hline
\end{tabular}

It is derived from Tables 3 that debit and credit related cases constitute almost half of the disputed cases. While 142 over 282 cases are related to 'Debit and Credit', 63 over 282 cases are related to 'Defective Products'. These are followed by 'Delay' with 32 cases, 'Termination of Contract' with 22 cases, 'Registration and Nullification for Deed and Title' with 21 cases and 'Occupational Accident' with 2 cases. The study of İlter and Bakioğlu [9] also support this finding by stating that debit and credit related dispute types such as price adjustment requests, additional payment requests, unit price determination and owner cash flow problems appear as the most frequent dispute types in construction projects.

Secondly, all the 282 cases are reviewed in terms of project types of concerned cases; then, project types are grouped as per 'Civil', 'Mechanical', 'Electrical', 'Infrastructure', 'Design', 'Finishing Works', 'Electrical/Mechanical' and 'Auditing'. Frequency of aforementioned project types is illustrated in Table 4 below. 
Table 4. Frequency of Project Type

\begin{tabular}{|l|c|c|}
\hline Project Type & \# of Cases & Percent (\%) \\
\hline Construction Works & 169 & 59.9 \\
\hline Finishing Works & 36 & 12.8 \\
\hline Mechanical & 26 & 9.2 \\
\hline Infrastructure & 26 & 9.2 \\
\hline Electrical & 12 & 4.3 \\
\hline Electrical/Mechanical & 5 & 1.8 \\
\hline Design & 4 & 1.4 \\
\hline Auditing & 4 & 1.4 \\
\hline Total & $\mathbf{2 8 2}$ & $\mathbf{1 0 0 . 0}$ \\
\hline
\end{tabular}

Construction works define the projects such as housing, hospital etc. which contain other related disciplines provided in Table 4 above as well as civil works. According to the table, projects related to construction works are detected as the main problematic areas with the number of 169 over 282 cases and while this corresponds to approximately $60 \%$ of the overall cases, finishing works ranks as the second by almost $13 \%$. Since projects concerning construction works mostly contain many divisions such as civil works, finishing works, mechanical works, electrical works, design etc., coordination between the disciplines carries many risks in terms of dispute. This fact clarifies the high occurrence rate of construction works. Thus, attention to the projects containing multi-disciplinary works is to be closely paid during the project life cycle.

Considering the disputes arising from both project types and dispute types, cross tabulation is needed to deeply investigate the main dispute sources. Therefore, Table 5 is generated for this matter.

It is derived from Table 5 that disputes mostly occur in Construction Works with the issues concerning debit and credit by $25 \%$, defective product by $12 \%$, Delay by $10 \%$. Each of other correlations constitutes less than $10 \%$.

Thirdly, 282 cases are reviewed in terms of Scope of Construction Project Contract and they are grouped as per 'Contract between Employer and Contractor', 'Contract of Flat in Return for Land', 'Design Contract' and 'Building Audit Contract'. Frequency of given Scope of Construction Project Contract is demonstrated in Table 6 below.

With respect to Scope of Construction Project Contract, while 'Construction Contract excluding Contract of Flat in Return for Land' corresponds to $71.6 \%$ of the total cases, 'Contract of Flat in Return for Land' constitutes $25.9 \%$ of the cases, which covers approximately a fourth of the total types. Cases associated with the issue of 'Contract of Flat in Return for Land' accelerated after the Urban Transformation legislation released on December 15, 2012 was established. 62 over 73 cases concerning 'Contract of Flat Return 
Murat ÇEVIKBAŞ, Almula KÖKSAL

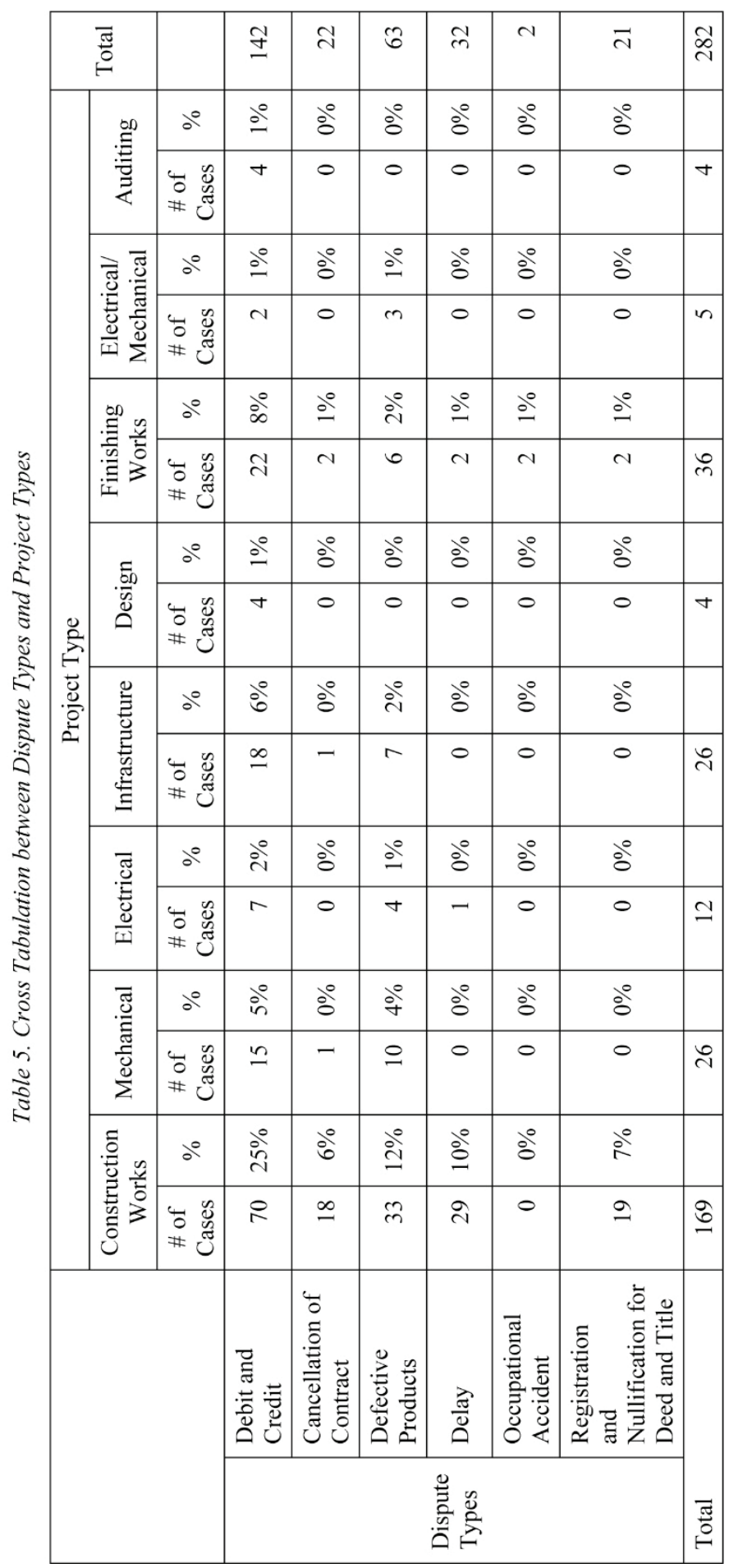


for Land' were conducted after December 15, 2012. Annual construction amounts have increased due to some privileges. This legislation provides the contractors and house owners to renew the existing buildings, and the number of cases related to 'Contract of Flat Return for Land' has increased accordingly.

So far, as stated in the purpose of this study the main problem areas in the content of the cases concerning construction industry along with their occurrence rates of disputes are classified. Next, 282 cases are reviewed in terms of decisions of Court of Cassation and it is categorized as per Reassessment decisions with 'Needs for Expert Judgment', 'Unsuitable Case Condition', 'Missing Review and Wrong Assessment', 'Defective Expert Report', 'Decision of Rejection of Venue', 'Not Offering Taking an Oath', and approving the 'Judgment' and 'Judgment with a Correction'. Frequency of given decisions by Court of Cassation is demonstrated in Table 7 below.

Table 6. Frequency of Scope of Construction Project Contract

\begin{tabular}{|l|c|c|}
\hline Scope of Construction Project Contract & $\begin{array}{c}\# \text { of } \\
\text { Cases }\end{array}$ & $\begin{array}{c}\text { Percent } \\
\text { (\%) }\end{array}$ \\
\hline Construction Contract excluding Contract of Flat in Return for Land & 202 & 71.6 \\
\hline Contract of Flat in Return for Land & 73 & 25.9 \\
\hline Building Audit Contract & 4 & 1.4 \\
\hline Design Contract & 3 & 1.1 \\
\hline Total & $\mathbf{2 8 2}$ & $\mathbf{1 0 0 . 0}$ \\
\hline
\end{tabular}

Table 7. Frequency of Determination by Court of Cassation

\begin{tabular}{|l|l|l|}
\hline Decision by Court of Cassation & \# of Cases & Percent (\%) \\
\hline Reassessment - Missing Review and Wrong Assessment & 123 & 43.6 \\
\hline Reassessment - Needs for Expert Judgment & 83 & 29.4 \\
\hline Reassessment - Defective Expert Judgment Report & 33 & 11.7 \\
\hline Reassessment - Decision of Rejection of Venue & 21 & 7.4 \\
\hline Reassessment - Unsuitable Case Condition & 7 & 2.5 \\
\hline Approving Verdict with a Correction & 6 & 2.1 \\
\hline Approving the Verdict & 5 & 1.8 \\
\hline Reassessment - Not Offering Taking an Oath & 4 & 1.4 \\
\hline Total & $\mathbf{2 8 2}$ & $\mathbf{1 0 0 . 0}$ \\
\hline
\end{tabular}

While Court of Cassation approves the verdicts of Courts of First Instance by only 3.9\%, Court of Cassation decides to reassess the cases conducted by Courts of First Instance by 96.1\%. Of all the reassessment reasons, 'Missing Review and Wrong Assessment' made by 
Courts of First Instance constitutes the biggest part of the decisions of reassessment with the number of 123 cases. The reason for second reassessment decisions due to lack of expert judgment in the cases, cover approximately $30 \%$ of all the cases.

Considering the overall 282 cases, Court of Cassation accepts 11 verdicts dealt by the Courts of First Instance, whereas remaining 271 cases are decided to be reassessed. In other words, around $96.1 \%$ of the cases carried to Court of Cassation are found incorrect and required to be reassessed. It can be derived from these findings that most decisions of Courts of First Instance are found unsatisfying. Considering the actors contributing to the wrong decisions given by the Court of First Instance, the associated errors namely, 'Missing Review and Wrong Assessment', 'Need for Expert Judgment', 'Decision of Rejection of Venue', 'Unsuitable Case Conditions' and 'Not Offering Taking an Oath' which are provided in Table 7 are related to the qualifications and competency levels of the judicial parties. The reassessed cases due to inadequate qualifications and competency levels of judicial parties correspond to approximately $85 \%$. Aside from judicial knowledge, technical and process related knowledge in construction would decrease wrong decisions and considerably shorten a lengthy process of litigation. The assessments of the cases also indicate that the qualification of chosen experts is another problematic area that needs to be focused. Around $12 \%$ of the reassessed cases have resulted from the experts' defective reports.

According to the legal process, if Court of First Instance insists on its decision and refuses the reassessment decision of the Court of Cassation, the case is evaluated again by the General Assembly of Civil Chamber which takes place under Court of Cassation [14]. It has been found that 6 cases over 282 cases were dealt with the General Assembly of Civil Chambers. It means that Courts of First Instance conducting these 6 cases disagreed with the reassessment decision given by the Court of Cassation. Still, reassessment decisions were given for 5 of the cases again.

In this study as the final step, relations between types of disputes and determinations made by Court of Cassation are presented in Table 8 below.

Considering the dispute types and determinations made by the Court of Cassation, the most notable findings are given as follows; debit and credit related cases are associated with 64 reassessment decisions due to missing reviews and wrong assessments made by Court of First Instance and 41 reassessment decisions are made due to needs for experts. The most remarkable findings derived from Table 8 are that the 'Needs for expert judgment' constitute almost $30 \%$ of the total cases. Almost half of the cases (41 cases) in this category are related to debit and credit issues between the project stakeholders mainly the general contractors and the owners. That is followed by the determination of the defective products by 27 cases, delay in projects by 8 cases, registration and nullification for deed and title by 7 cases. Each issue in this process needs knowledge of construction process by the judicial actors in order to determine the conditions of cases. The findings indicate that unqualified expert reports cause courts to make inappropriate decisions. Encouraging the utilization of qualified experts in the courts with regard to these areas is believed to improve the success of the litigation process. In Table 8, 'Missing Review and Wrong Assessment' constitute 44\% of the cases. Half of the cases in this category and $23 \%$ of the total cases constitute 'Debit and credit' issue. These outcomes indicate the lack of construction specific knowledge during the decision making process. 


\begin{tabular}{|c|c|c|c|c|c|c|c|c|c|}
\hline & \multirow{2}{*}{ है } & $\partial^{\circ}$ & in & $\infty$ & ป & $=$ & - & $r$ & $\S$ \\
\hline & & 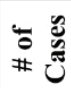 & I & ป & $\hat{6}$ & กี & 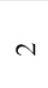 & $\bar{v}$ & 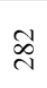 \\
\hline & \multirow[t]{2}{*}{ 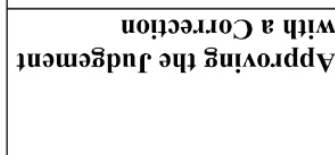 } & $0^{\circ}$ & - & 0 & - & 0 & 0 & 0 & $\mathrm{n}$ \\
\hline & & 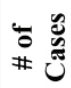 & m & 0 & $\mathrm{~N}$ & - & 0 & 0 & 0 \\
\hline & \multirow[t]{2}{*}{ 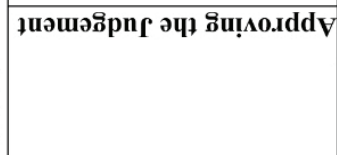 } & $0^{\circ}$ & 0 & - & 0 & 0 & 0 & 0 & 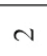 \\
\hline 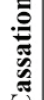 & & 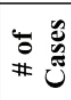 & - & $m$ & 0 & 0 & 0 & - & $n$ \\
\hline 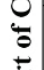 & \multirow[t]{2}{*}{ 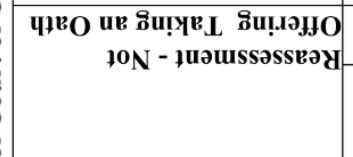 } & $\theta^{\circ}$ & - & 0 & 0 & 0 & 0 & 0 & - \\
\hline$\dot{e}_{\overline{0}}^{\grave{z}}$ & & 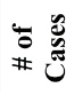 & 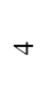 & 0 & 0 & 0 & 0 & 0 & 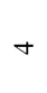 \\
\hline : & \multirow{2}{*}{ 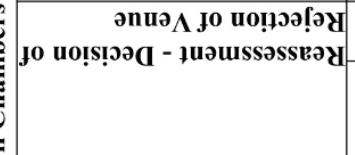 } & $\partial^{\circ}$ & $\mathrm{a}$ & - & - & - & - & - & $n$ \\
\hline $\begin{array}{l}\frac{\pi}{\tilde{U}} \\
\frac{\pi}{5}\end{array}$ & & 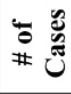 & n & $\nabla$ & $m$ & $m$ & $\mathrm{n}$ & $\mathrm{N}$ & $\bar{v}$ \\
\hline ż & \multirow[t]{2}{*}{ 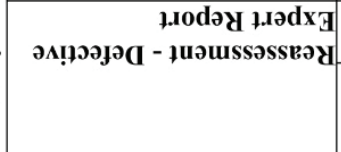 } & $\theta^{\circ}$ & 0 & $N$ & $\mathrm{a}$ & $\mathrm{N}$ & 0 & 0 & $\simeq$ \\
\hline .气气 & & 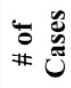 & $\beth$ & in & $n$ & 0 & 0 & 0 & $m$ \\
\hline \multirow{6}{*}{ 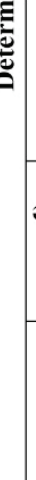 } & 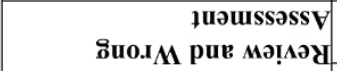 & $\partial^{\circ}$ & $\hat{\imath}$ & $m$ & $a$ & in & 0 & t & Ұ \\
\hline & 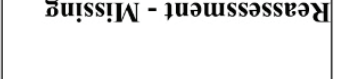 & 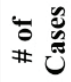 & ț & $a$ & $\approx$ & $\Xi$ & 0 & $=$ & 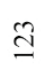 \\
\hline & 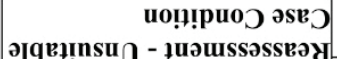 & $a^{\circ}$ & $a$ & o & 0 & 0 & 0 & 0 & $\mathrm{~N}$ \\
\hline & & 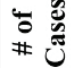 & $n$ & - & - & 0 & 0 & 0 & $r$ \\
\hline & 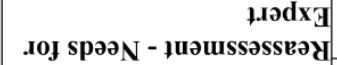 & $0^{\circ}$ & $\cong$ & o & 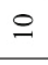 & $m$ & o & $\alpha$ & নे \\
\hline & & 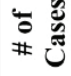 & $\exists$ & 0 & $\hat{\imath}$ & $\infty$ & 0 & $r$ & $\infty$ \\
\hline \multicolumn{3}{|c|}{ 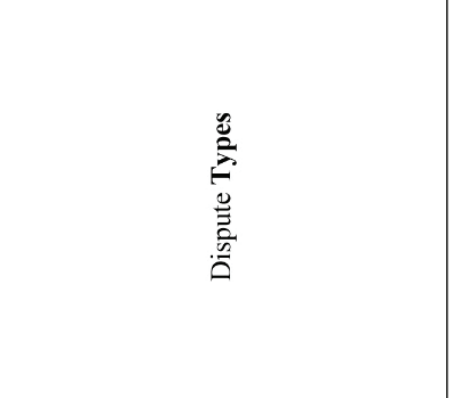 } & 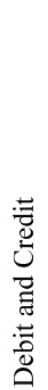 & 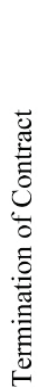 & 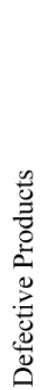 & $\frac{\grave{J}}{0}$ & 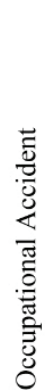 & 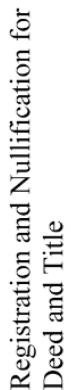 & हّٓ \\
\hline
\end{tabular}




\section{CONCLUSION}

In this study, initially, 282 cases conducted by Court of Cassation between the years 2007 and 2017 in Turkey are reviewed and the content of the cases along with their occurrence rates are classified as per articles in Contract of Work, dispute types, project types, Scopes of Construction Project Contracts in order to detect the problematic areas in the contents of the cases. Secondly, it is aimed to identify the competency levels and qualifications of actors in the judicial system for construction related cases in Turkey. In order to achieve this goal, the classification of determinations made by the Court of Cassation is utilized. Following the in-depth review of the cases and the classification, the data is analysed via SPSS as a quantitative study. As a consequence, it is derived from the analysis that contract is the most common dispute reason in construction. Because, the majority of contracts are not focused to an analytical approach for dispute resolution, which is also identified by Ilter [13]. Additionally, of the contracts drawn up in the construction sector in Turkey, $70 \%$ of them were drafted without considering any type of existing standard contacts [19] Thus, concerning contractual problems, it is highly beneficial for construction projects to deeply investigate the contents of the contracts made to be able to take significant precautions against negative impacts of potential disputes. In conclusion, the amount of disputes related to contracts would be reduced. With respect to disputes resulting from contract, it is found that civil projects such as buildings or any other related turnkey projects containing more than one discipline carry higher probability of risks; therefore, close attention is to be paid to these kinds of projects during the contract stages of the projects in order to prevent the amount of potential disputes by eliminating ambiguities.

Contents of 'Construction Contract excluding Contract of Flat in Return for Land' and 'Contracts of Flat in Return for Land' are presented as the biggest sensitive areas in dispute. When the contents of contracts are investigated, monetary issues under the title of debit and credit rank as the most frequent dispute source related to contracts. This is followed by defective products. Therefore, while initiating the construction project contract, these subjects are to be taken into consideration highly to eliminate disputes during the course of the projects.

'Missing Review and Wrong Assessment' is detected as the major factor contributing to wrong determinations of Courts of First Instance by $43.6 \%$. It is followed by 'Needs for Expert Judgment' by 29.4\%, 'Defective Expert Report' by $11.7 \%$, 'Decision of Rejection of Venue' by $7.4 \%$, 'Unsuitable Case Condition' by $2.5 \%$ and 'Not Offering Taking an Oath' by $1.4 \%$. It is claimed that the success of judgment would definitely increase by assigning the correct expert to the cases considering technical issues. Additionally, qualifications of experts also need to be reconsidered by the legislators, judicial actors, and trade chambers. Excluding 'Defective Expert Judgment' Reports', all the reasons concerning reassessment decisions by Courts of First Instance stem from inadequate qualifications and competency levels of the other judicial actors namely, judges and lawyers. This corresponds to approximately $85 \%$ of the total cases. This outcome indicates the qualifications of judges and lawyers as another problematic area affecting dispute resolution process. Construction industry has its own characteristics like industries of Medicine and Information Technology (IT) and requires specific knowledge in order to resolve any dispute concerning construction. Therefore, improving technical knowledge of construction of these judicial actors is believed to improve the success of the judicial process. 
According to the final legislation related to experts, which was released on November 3, 2016 with the law number 5754, people graduating from faculties of law cannot be enrolled in the expert registry unless they have specialist expertise outside the legal field. This new legislation is believed to reinforce the qualifications and competency levels of experts and it is thought to reduce the experts' defective reports in the upcoming cases. It can be concluded that litigation processes are mostly prolonged due to inadequate qualifications and competency levels of judicial actors; thus, not only the judicial process but also the parties in construction projects are exposed to inconvenient prolongation of works.

Since this study is limited with investigating the cases conducted only by the Court of Cassation in Turkey between 2007 and 2017 to identify solely the sources of disputes and current qualifications and competency levels of judicial actors, further studies can be conducted beyond the limitations of this worek. This study can be enhanced through contributions of other actors participating in judicial processes concerning construction like contractors, claimants, defendants etc. This study is believed to highlight the bottlenecks of the construction projects and judicial process concerning construction industry, and guide the judicial actors and parties participating in construction related cases. Finally, this study is believed to contribute to future studies concerning development of standard construction project contracts and the improvement of litigation process as one of the dispute resolution methods.

\section{References}

[1] PMI, Guide to the Project Management Body of Knowledge (PMBOK), 5 ed., Pennsylvania. PMI Publications, 2013.

[2] Sanghera, P., PMP In Depth Project Management Professional Study Guide for the PMP Exam, 4 ed., Boston. Course Technology PTR, 2010.

[3] Iter, D., Dikbaş, A., Less, M., Alternative Dispute Resolution: Suggestions for Application in the Turkish Construction Industry, Construction Management and Economics Conference (CME25), Reading, 2007.

[4] Oxfordbusinessgroup, Oxford Business Group, 2017. [Online]. Available: https://www.oxfordbusinessgroup.com/overview/turkeys-construction-sectormaintain-its-significant-role-economy-several-large-projects-under-way. [Accessed 05 05 2017].

[5] İlter, D., Dikbaş, A., An analysis of the key challenges to the widespread use, International Journal of Law in the Built Environment of mediation in the Turkish construction industry, 1, 2, 143-155, 2009.

[6] Cheung, S., Suen, H. C. H., Lam, T., Fundamentals of Alternative Dispute Resolution Processes in Construction, Journal of Construction Engineering and Management, 128, 5, 409-417, 2002.

[7] Harmon, K. M. J., Resolution Of Construction Disputes: A Review of Current Methodologies, Leadership and Management in Engineering, 3, 4, 187-201, 2003. 
[8] İlter, D., Dikbaş, A., An investigation of the factors influencing dispute frequency in construction projects, RICS COBRA Research Conference, University of Cape Town, Cape Town, 2009.

[9] İler, D., Bakioglu, G., Modeling the Relationship between Risk and Dispute in Subcontractor Contracts, Journal of Legal Affairs and Dispute Resolution in Engineering and Construction, 10, 1, 04517022-1-9, 2018.

[10] Apanoğlu, E. C., Türkiye'de inşaat sektöründe yargiya intikal eden süre ve özen borcu kaynaklı anlaşmazlıkların analizi, Yüksek Lisans, Çukurova Üniversitesi Fen Bilimleri Enstitüsü, 2007.

[11] Büyüköztürk, Ş., Kılıç Çakmak, E., Akgün, Ö. E., Karadeniz, Ş., Demirel, F., Bilimsel Araştırma Yöntemleri, 17th ed., Ankara. Pegem Akademi, 2014.

[12] Yıldırım, A., Şimşek, H., Sosyal Bilimlerde Nitel Araştırma Yöntemleri, 9. ed., Ankara. Seçkin Yayıncılık, 2013.

[13] İler, D., Opinions of Legal Professionals Regarding the Selection of Appropriate Resolution Method in Construction Disputes, RICS \& CIB International Research Conference (COBRA 2010), Paris, 2010.

[14] Mevzuat.gov.tr, Hukuk Muhakemeleri Kanunu, 0402 2011. [Online]. Available: http://www.mevzuat.gov.tr/MevzuatMetin/1.5.6100.pdf. [Accessed 1302 2017].

[15] Gözler, K., Hukukun Temel Kavramları, 12 ed., Bursa. Ekin Basım Yayın Dağıtım, 2014.

[16] TC-Yargıtay-Başkanlığı. [Online]. Available: http://www.yargitay.gov.tr/sayfa/organization-chart/673. [Accessed 1605 2017].

[17] TBMM, Türk Borçlar Kanunu, 1101 2011. [Online]. Available: https://www.tbmm.gov.tr/kanunlar/k6098.html. [Accessed 1002 2017].

[18] C. Bvumbwe and D. Thwala, An Exploratory Study of Dispute Resolution Methods in the South African Construction Industry, International Conference on Information and Finance, Singapore, 2011.

[19] İlter, D., İnşaat Projelerinde Uyuşmazlık Çözüm Yöntemi Seçimi İçin Çok Kriterli Karar Verme Modeli, Doctoral thesis, İstanbul Technical University Graduate School of Science Engineering and Technology, İstanbul, 2010. 
